\title{
The Value Relevance of Audit report, Auditor Type and Auditor Tenure: Evidence from Iran
}

\author{
Bahman Banimahd \\ Department of Accounting, Science and Research Branch \\ Islamic Azad University (IAU), Tehran, Iran
}

Tel: 98-91-2567-1123Ｅ-mail: dr.banimahd@gmail.com

Zahra Poorzamani

Department of Accounting, Science and Research Branch

Islamic Azad University (IAU), Tehran, Iran

Tel: 98-91-2350-2196_E-mail: Zpoorzamani@yahoo.com

Saeid Ali Ahmadi (Corresponding author)

Science and Research Branch, Islamic Azad University (IAU), Tehran, Iran

Tel: 98-91-6364-3340_E-mail: saeidaliahmadi@yahoo.com

Received: Dec. 2, 2012 Accepted: January 30, 2013 Published: June 1, 2013

doi:10.5296/ajfa.v5i1.2787 URL: http://dx.doi.org/10.5296/ajfa.v5i1.2787

\begin{abstract}
The aim of this paper is to investigate the value relevance of the audit report, auditor type and auditor tenure in the Iranian context. This study evaluates the effects of various independent variables on the value relevance using a multiple regression analysis approach for 156 companies listed on the Tehran Stock Exchange (TSE) over a 10 year period. The results indicate that audit report has not the value relevance. Hence, unqualified audit report and other audit report are not different in capital market. Empirical results showed that the auditor type has a positive impact on the value relevance. This result is consistent prior studies. Thus, the value relevance of firms audited by government audit has more than firms audited by private audit. Also, when the tenure of auditors is long, it has a negative impact on the value relevance. This result is consistent prior studies. The empirical evidence indicates that audit
\end{abstract}


report is not valued by the capital market in Iran and that audit privatization impact on the value relevance in capital market. Hence, the market regulators proposed that the more monitoring considered on audit quality to improve the value relevance in capital market. The results presented in the paper have important implications for both the auditing profession and regulators in Iran.

Keywords: Value relevance, Audit reports, Type of Auditor, Tenure of Auditor 


\section{Introduction}

One of the primary issues in accounting-based capital market researches in recent years has been the value relevance of accounting information. The related studies indicate that summarized accounting measure is associated with firm value (Brown et al., 1999; Barth et al., 2001; Holthausen and Watts, 2001; Lee and Wang, 2003). Value relevance is defined as the ability of financial statements information to capture or summaries information that affects shared value (Francis and Schipper, 1999). Empirically, an accounting amount is deemed value relevant if it has an association with equity market values and, if the accounting number increases the power of the estimating equation in estimating market values, then an accounting number is deemed relevant with some reliability (Barth, 2006).

This study is examined the value relevance of the audit report, type of auditor, and tenure of auditor in Iran context. Auditors, by doing audits in accordance with the generally accepted auditing standards (GAAS), will attest to the fairness of corporate financial reports by detecting and reporting material deviations from the generally accepted accounting standards to various stakeholders (lin and et al, 2009). Hence, independent audit can decrease the asymmetry information and agency problem. Audit opinion about accounting information by the decrease of agency problem can provide the usefulness of accounting information to the capital market participants. The usefulness of accounting information can effect on the decision making of users. So, in order to increase the usefulness of accounting information, auditors add the assurance of financial information which it can results to increase the value relevance. Hence, when audit report has value relevance, it can improve decisions of users about rational investment, credit, and etc. Thus, it expected that audit report (i.e. unqualified audit report or other audit report) can effect on positively the value relevance and a positive signal send to capital market. Private audits or Audit Organization audited Companies listed in Tehran Stock Exchange (TSE). Audit Organization is the biggest audit firm in Iran context and because of law support have high independent. Thus, it expected that type of audit (i.e. private audit or Audit Organization) can impact on positively the value relevance and a positive signal transfer to capital market. Because the acquaintance of audit firms with accounting information system, firm's productions, the firm policies, and the industry activates and so on, Audit firms tendency to preserve the relation to clients. If the tenure of auditor is long time, auditor independent may decline and thus, the value relevance of accounting information decrease in during time and a negative signal convey to capital market. So, it expected that tenure of auditor can impact negatively on the value relevance.

This study investigates the value relevance of audit phenomena after audit privatization and the increase of audit competition in Iranian audit market. This may affect agency costs, audit independent and other factors that can impact on the value relevance of accounting information. Audit privatization happened in 2001 in Iran by establishing Iranian Association of Certified Public Accountants (IACPA). Audit privatization result to decline the government auditor monopoly over the audit of government controlled companies listed in TSE. 
This study have motivated by tow factors. First, a key distinction between our study and prior study (such as lin and et al (2009)) is the differences in the research design. Against the prior studies, this research uses a longer test window. The longer test window captures stock price changes based on both information before public disclosure and information drifts after disclosure (lin and et al, 2009). Second, because of Audit privatization and the increase of competition among auditors in the emerging capital market of Iran may be the value relevance of audit factors such as audit report, type of auditor and the tenure of auditor differed from the other countries. So, these variables should be empirically examined in the emerging capital market of Iran.

The primary and main question of this study is whether audit report, type of auditor and tenure of auditor has value relevance in the emerging capital market of Iran or not. This paper contributes to the auditing literature on the audit privatization and their effects on the value relevance in an emerging market. Considering occur audit privatization in capital market, the value relevance of audit factors have survey less than the other subject of value relevance studies and so, need to more explore in the developed and developing countries.

The remainder of the paper is organized as follows: Section 2 illustrates audit and accounting environment in Iran. Section 3 introduces relevant prior studies. Section 4 describes hypothesis development. Section 5 describes research methodology. Section 6 presents sample selection. Section 7 presents and discusses the empirical results of this study. Finally, Section 8 gives a brief summary and conclusion.

\section{Audit and Accounting Environment in Iran}

Emergence of a developing financial market due to privatization and economic growth and development have increased the need for accountants and auditors in Iran, and have caused the accountancy-related issues to be more seriously addressed. The legal system is considered as an important factor affecting on accounting system (Nobes, 1983), and particularly in Iran, the legal system is probably the most influential determinant of accounting discipline.

\subsection{Audit Organization (AO)}

Audit Organization, established in 1987, is a governmental institution which takes the responsibility of accounting and auditing in Iran. The organization is a part of Ministry of Economic Affairs and Finance, and includes Accounting and Auditing Standards Setting Committees which are legal authorities to set accounting and auditing procedures. Audit Organization is the only regulatory body in charge of setting accounting and auditing standards in Iran. By the end of 2011, 32 accounting standards and 37 auditing standards had been passed in committees.

Audit Organization has the responsibility for auditing governmental companies and most other organizations with public ownership. In fact, Audit Organization is by far the biggest auditor firm in Iran. Approximately half the audits in Iran are conducted by Audit Organization. This situation is frequently objected by private audit firms and has created an intense competitive audit market for non-governmental auditors to attract more clients from 
the other half of audit market and also attempt to reduce Audit Organization market share (Farajzade and Makarem, 2011).

\subsection{Tehran Stock Exchange (TSE)}

Tehran Stock Exchange (TSE) was founded in 1967. In the first year, only six companies were in the TSE list. In 1989 along with the revitalization of the private sector and privatization of the state-owned enterprises, a new economic program began to develop the promotion of private sector activities. This coincided with the time that the first five-year national development plan in the country was at the initial stage of designing. In fact, the TSE has grown as one of the most important executive mechanism for promoting the national economy. This aimed at the environment facilitating contribution of the private sector in productive programs actively, transferring some state duties to the private sector and mobilizing private savings into investment programs. Since then the stock exchange market has grown continuously till today. In recent years, the TSE has evolved into an exciting and growing marketplace for many investors. Now there are more than 460 companies in the TSE investors' trade-in securities hall. The new Capital Market Law was passed in November 2005, forty years since the establishment of the TSE. Under the new law, TSE would be restructured and incorporated in the private investment. (Pourheydari and Ali Ahmadi, 2008)

\subsection{Iranian Association of Certified Public Accountants}

Invoking a bill ratified by parliament, Iranian Association of Certified Public Accountants (IACPA) was established in 2001. Based upon the bill, government is allowed to use professional services of certified public accountants. Only IACPA members are permitted to establish audit firms. Currently, auditing of governmental companies is mostly carried out by $\mathrm{AO}$ and other entities are audited by other audit firms. Although AO is not prohibited from auditing of non-governmental companies, its major activity is concentrated on public sector. IACPA is ambitiously exerting pressure on the government to gain the power to set accounting and auditing standards, and also to enjoy the right to audit more government-affiliated firms (Farajzade and Makarem, 2011).

According to TSE regulations, all listed companies are required to prepare audited financial reports confirmed by reliable auditors. Reliable auditors are those audit firms that meet additional criteria set by TSE. By the end of 2011, more than 100 audit firms along with AO were adopted by TSE as reliable auditor (Farajzade and Makarem, 2011).

\section{Literature Review}

In this section the several of studies have been presented that are approximately related to the value relevance of audit factors such as audit report, type of auditor and tenure of auditor.

Ittonen (2012) review the archival literature on market reactions to qualified audit reports and to seek to identify the different approaches used in those studies. The result suggests that there are three main approaches used in the literature: the short-window approach, the long-window approach, and the indirect approach. 
Kang-tao and Ying-li (2011) investigates whether audit quality can increase the value relevance of fair value accounting. The results indicate that fair value accounting information has incremental value relevance and Big 4 auditing firms can improve the value relevance of fair value accounting information.

The relationship between audit quality and value relevance of accounting information is explored by Lee and Lee (2011). They survey the effect of a firm's future profitability on its book value, when estimating the explanatory power of book value to stock return. The results show that when the big-five of audit firm audited the earnings and book value, it explains more variations in stock return than those audited by other firms. Hence, the value relevance of earnings and book value for firms which audited by the big-five of audit firms are more than other firms.

The market reaction to auditor switching from big 4 to third-tier small accounting firms is investigated by Chang and et al. (2010). They used the period of 2002 to 2006. Based on regulatory changes, they separate sample period into two segregate periods. The result showed a relatively more positive stock market reaction to clients switching from a big 4 to a smaller third-tier auditor in period 2. When an audit quality is decrease, this relatively more positive reaction in period 2 reflects companies seeking better services rather than a lower audit fee.

Bich Ngoc (2010) explored the value relevance of accounting information for investment by large listed company in Vietnamese stock market. He addresses that whether accounting information affects the decision of investor and the frequency of the use of information by investors. The result of this research shows that accounting information is an important reference source when investors make investment decisions.

Ittonen (2009) investigated the relevance of auditors' going concern and internal control reports to investors. The sample consists of Russell 3000 Index firms. It includes 237 firms with going concern audit reports. The results confirm that the audit reports studied contain some relevant information to the investors.

Ghosh and Moon (2005) address that whether auditor tenure impair audit quality or not. The result shows that earnings response coefficients increase with the length of audit firm tenure, consistent with earnings having a greater influence on equity prices as auditor tenure increases.

Balsam and et al. (2003) examined the relationship between quality and information content of earnings regarding audit quality. They concluded that the audit quality in companies with a high earnings quality and information content of earnings is more than those companies which possess a low range of the two mentioned factors.

Martinez and et al. (2003) examine the reaction of Spanish capital market to qualified audit reports. They address whether there is a relationship between audit qualifications and stock prices in the context of the Spanish market. The event study methodology for this purpose used. The results indicate that qualified audit reports do not have information value for investors. 


\section{Hypothesis Development}

The audited accounting information is to enable the auditor to state an opinion as to whether financial statement present fairly. Audit opinions are public documents used by auditors as a method in communicating the results of the work to the principal and other users of the report. Audit reports are useful in the decision making of users if it can convey a signal to users and lead to reaction in capital market. Thus, audit reports can have value relevance and the unqualified or other audit report can different the value relevance in market capital. So, it expected that the value relevance increase when firm have unqualified audit report. To examine the effects of audit report on the value relevance, the following hypotheses are set:

$\mathrm{H}_{1}$ : Audit report has the value relevance in Iran context.

Accounting and audit information is value relevance if it effect on the users decision making. Firms which audited by independent auditors can assure to users about disclosed information. Thus, the assurance conveys a positive signal to capital market and result to market reaction. As discussed before, Audit Organization (AO) is as the biggest Iranian audit provider and it concentrates on governmental companies and the most other organizations with public ownership. This provides Audit Organization with a considerable independence; enabling it to conduct its audits without fear of losing its clientele. Thus, we expect that Audit Organization have the value relevance more than the private audit. To examine the effects of the type of auditor on the value relevance, the following hypothesis is empirically tested:

$\mathrm{H}_{2}$ : Auditor type has the value relevance in Iran context.

Independent audits enhance the credibility of corporate financial reports and assist investors to make rational decisions in the capital market. The users are perceived to gain benefits from the increased credibility. These benefits are typically considered to be that the quality of investment decisions are improved when they are based on reliable information. But, when the tenure of auditors is long, it may have a negative effect on the value relevance and hence, a negative signal convey to the capital market because auditors who perform over the long term may give up their independence to maintain close relationships with their clients. So, it expected that the value relevance is decrease when the tenure of auditors is long term. To examine the effects of the tenure of auditor on the value relevance, the following hypotheses are set:

$\mathrm{H}_{3}$ : Auditor tenure has the value relevance in Iran context.

In order to examine the combine of independent variables such as the audit report, auditor type and the tenure of auditor, the following hypotheses are set:

$\mathrm{H}_{4}$ : Audit report and auditor type have the value relevance in Iran context

$\mathrm{H}_{5}$ : Audit report and auditor tenure have the value relevance in Iran context

$\mathrm{H}_{6}$ : Auditor type and auditor tenure have the value relevance in Iran context

$\mathrm{H}_{7}$ : Audit report, auditor type and auditor tenure have the value relevance in Iran context 


\section{Research Methodology}

In this paper in order to test of hypothesis we used seven equations have been developed to test $\mathrm{H}_{1}-\mathrm{H}_{7}$. This research for the test of hypothesis applied a long test window. The long test window is base on the value relevance studies. The ohlson (1995) model used in the value relevance studies. Ohlson model (1995) indicates that value is a weighted function of earnings and book value. According to research of Brown and et al. (1998), in this research we used lagged price as a scale proxy to deflate price per share, book value per share and earnings per share. We define value relevance as the association between accounting information and equity market values (Francis and Schipper, 1999; and Barth, Beaver and Landsman, 2001). In this paper depended variable is price per share and independent variables include the book value per share, earning per share, report of audit, type of auditor and tenure of auditor. Equations are illustrated as the following:

$$
\begin{aligned}
& \frac{P_{i t}}{P_{i t-1}}=\alpha_{1}+\alpha \frac{B V_{2}}{P_{i t-1}}+\alpha \frac{E P S_{i t}}{P_{i t-1}} \alpha_{4} A R_{i t}+\varepsilon_{i t} \\
& \frac{P_{i t}}{P_{i t-1}}=\alpha_{1}+\alpha \frac{B V_{i t}}{P_{i t-1}}+\alpha \frac{E P S_{i t}}{P_{i t-1}}+\alpha_{4} A T_{i t}+\varepsilon_{i t} \\
& \frac{P_{i t}}{P_{i t-1}}=\alpha_{1}+\alpha \frac{B V_{2}}{P_{i t-1}}+\alpha \frac{E P S_{i t}}{P_{i t-1}}++\alpha_{4} A T E_{i t}+\varepsilon_{i t} \\
& \frac{P_{i t}}{P_{i t-1}}=\alpha_{1}+\alpha \frac{B V_{i t}}{P_{i t-1}}+\alpha \frac{E P S_{i t}}{P_{i t-1}}+\alpha_{4} A R_{i t}+\alpha_{5} A T_{i t}+\varepsilon_{i t} \\
& \frac{P_{i t}}{P_{i t-1}}=\alpha_{1}+\alpha \frac{B V_{i t}}{P_{i t-1}}+\alpha \frac{E P S_{i t}}{P_{i t-1}}+\alpha_{4} A R_{i t}+\alpha_{5} A T E_{i t}+\varepsilon_{i t} \\
& \frac{P_{i t}}{P_{i t-1}}=\alpha_{1}+\alpha \frac{B V_{i t}}{P_{i t-1}}+\alpha \frac{E P S_{i t}}{P_{i t-1}}+\alpha_{4} A T_{i t}+\alpha_{5} A T E_{i t}+\varepsilon_{i t} \\
& \frac{P_{i t}}{P_{i t-1}}=\alpha_{1}+\alpha \frac{B V_{i t}}{P_{i t-1}}+\alpha \frac{E P S_{i t}}{P_{i t-1}}+\alpha_{4} A R_{i t}+\alpha_{5} A T_{i t}+\alpha_{6} A T E_{i t}+\varepsilon_{i t}
\end{aligned}
$$

Where $P_{i t}$ is price per share at four month after the end of fiscal year; $E P S_{i t}$ is earnings per share at the end of fiscal year; $B V_{i t}$ is book value per share at the end of fiscal year; $A R_{i t}$ is report of audit. It is dummy variable and set 1 if firm has an unqualified audit opinion, but 0 otherwise; $A T_{i t}$ is type of auditor. It is dummy variable and set 1 if firm audited by audit organization, but 0 otherwise; $A T E_{i t}$ is tenure of auditor in firm.

\section{Sample Selection}

Our sample covers listed companies in Tehran Stock Exchange (TSE) across the period from 2001 to 2010. The sample selection criteria are:

1. The end of fiscal year is March 201,

2. Data is available at least for seven years in period 2001 to 2010, and

\footnotetext{
1 - The end of fiscal year in Iran (i.e. Esfand 29) is equal March 20 data.
} 
3. The company is not loss frequently for three years.

In order to increase the numbers of firms in sample, we set second criterion. Summary of sample criteria presented as follow.

Table 1. Summary of sample selection criteria

\begin{tabular}{|c|c|c|}
\hline & $\begin{array}{c}\text { The number of listed } \\
\text { firms }\end{array}$ & $\begin{array}{c}\text { The percentage of } \\
\text { total population }\end{array}$ \\
\hline Firms that listed on the TSE between 2001 to 2003 & 364 & 100 \\
\hline \multicolumn{3}{|l|}{ Deduct: } \\
\hline Firms with fiscal year-end other than 20 March & (48) & $(13.18)$ \\
\hline Firms with missing data & (136) & $(37.36)$ \\
\hline Firm with loss frequently for more three years & (24) & $(6.59)$ \\
\hline Final Sample & 156 & 42.87 \\
\hline
\end{tabular}

\section{Results}

Descriptive statistics of this paper are showed in Tables 2 and 3. Price per share has a high standard deviation. The percent trend of type of audit indicates that audit privatization increase in the Iranian capital market during the last decade. Also, the percent trend of unqualified audit opinion is increase in the Iranian capital market during the last decade.

Table 2. Descriptive Statistics of qualitative variables

\begin{tabular}{|c|c|c|c|c|c|}
\hline & N & $\begin{array}{c}\text { Tymber of } \\
\text { Tyudit }\end{array}$ & $\begin{array}{c}\text { Per- } \\
\text { cent }\end{array}$ & $\begin{array}{c}\text { Number of unquali- } \\
\text { fied audit opinion }\end{array}$ & $\begin{array}{c}\text { Per- } \\
\text { cent }\end{array}$ \\
\hline 2001 & 132 & 81 & 61 & 28 & 5 \\
\hline 2002 & 142 & 77 & 54 & 42 & 8 \\
\hline 2003 & 150 & 64 & 43 & 52 & 9 \\
\hline 2004 & 153 & 47 & 31 & 57 & 10 \\
\hline 2005 & 154 & 48 & 31 & 60 & 11 \\
\hline 2006 & 155 & 42 & 27 & 64 & 12 \\
\hline 2007 & 154 & 41 & 27 & 65 & 12 \\
\hline 2008 & 156 & 39 & 25 & 62 & 11 \\
\hline 2009 & 154 & 36 & 23 & 65 & 12 \\
\hline 2010 & 150 & 36 & 24 & 59 & 11 \\
\hline
\end{tabular}


Table 3. Descriptive Statistics of quantities variables

\begin{tabular}{|l|c|c|c|}
\hline variables & $\mathrm{N}$ & Mean & $\begin{array}{c}\text { Std. } \\
\text { Deviation }\end{array}$ \\
\hline Adjusted price per share & 1437 & 1.09 & 0.82 \\
\hline $\begin{array}{l}\text { Adjusted book value per } \\
\text { share (BVPS) }\end{array}$ & 1487 & 0.60 & 0.56 \\
\hline $\begin{array}{l}\text { Adjusted earnings per } \\
\text { share(EPS) }\end{array}$ & 1427 & 0.16 & 0.26 \\
\hline Tenure of Audit & 1487 & 3.60 & 2.52 \\
\hline
\end{tabular}

The based on the result of limer test and Hausman test (Gujarati, 2004), we used the fixed effects regressions for testing of hypothesis. Table 4 presents regression summary statistics corresponding to the equations. The coefficient estimates, $\mathrm{t}$ - statistics, and Adjasted- $\mathrm{R}^{2}$ values are presented in Table 4. At or below a significant level 0.05 , the F-statistic is significant. This means that the whole of model is statistically significant in predicting price per share. The coefficients estimates ( $t$-student) in 1 to 7 model for earnings per share (EPS) are positively significant $\left(\mathrm{t}_{1}=5.52, \mathrm{t}_{2}=5.37, \mathrm{t}_{3}=4.49, \mathrm{t}_{4}=5.35, \mathrm{t}_{5}=4.81, \mathrm{t}_{6}=4.58, \mathrm{t}_{7}=4.58\right.$, significant at or below the 0.05 level). The coefficients estimates ( $t$-student) in 1 to 7 models for book value per share is positively significant $\left(\mathrm{t}_{1}=6.83, \mathrm{t}_{2}=7.34, \mathrm{t}_{3}=8.19, \mathrm{t}_{4}=7.32, \mathrm{t}_{5}=8.19, \mathrm{t}_{6}=8.55\right.$, $\mathrm{t}_{7}=8.78$, significant at or below the 0.05 level). Earnings per share and book value per share have the value relevance for Iranian investors.

Regarding our $\mathrm{H}_{1}$ hypothesis, table 4 reveals that audit reports is not significant $(\beta=-0.035, t=-0.60$, significant at or below the 0.05 level). This result indicates that unqualified audit report and other audit reports are not different the value relevance in capital market and not lead to market reaction. This result is inconsistent with hypothesis. In the other words, the value relevance of audit reports is not increase in capital market after implement audit privatization in Iran.

Regarding our $\mathrm{H}_{2}$ hypothesis, table 4 shows that type of auditor is positively significant $(\beta=0.33, t=4.20$, significant at or below the 0.05 level). This result suggests that firms audited by government audit have the value relevance higher than private audit. This finding is consistent with hypothesis. In the other words, Audit Organization with a considerable independence, enabling it to conduct its audits without fear of losing its clientele and hence, the value relevance the firms audited by Audit Organization are higher than the private audit. In all, firms audited by Audit Organization give a positive signal to the capital market and lead to the market reaction. Thus, audit privatization causes to different the value relevance between government audit and private audit.

Regarding our $\mathrm{H}_{3}$ hypothesis, table 4 reveals that the tenure of auditors have negatively significant $(\beta=-0.06, \mathrm{t}=-5.58$, significant at or below the 0.05 level). This finding is consistent with hypothesis. This result indicates that the tenure of auditors have a negative effect on the value relevance because auditors who perform over the long term may give up their independence to maintain close relationships with their clients. Also, the result indicate that 
the long term of the tenure of audit convey a negative signal to the capital market and result to decrease the value relevance.

Regarding our $\mathrm{H}_{4}$ hypothesis, table 4 shows that type of auditor is positively significant but audit reports is not significant $(\beta=0.33, \mathrm{t}=4.12, \beta=-0.0001, \mathrm{t}=-0.00$, significant at or below the 0.05 level). This result indicate that firms audited by government audit have the value relevance higher than private audit and result to market reaction but unqualified audit opinion and other audit reports are not different the value relevance in capital market and not lead to market reaction.

Regarding our $\mathrm{H}_{5}$ hypothesis, table 4 reveals that the tenure of auditor have negatively significant but audit reports is not significant $(\beta=-0.06, \mathrm{t}=-5.57, \beta=-0.05, \mathrm{t}=-0.86$, significant at or below the 0.05 level). This result indicates that the tenure of auditors has a negative effect on the value relevance and a negative signal send to market capital. In the other words, when the tenure of auditor is long term, the value relevance decrease. However, unqualified audit report and other audit reports are not different the value relevance in capital market and not a signal convey to capital market.

Regarding our $\mathrm{H}_{6}$ hypothesis, table 4 appears that firms with the tenure of auditors and type of auditor is negatively and positively significant in turn $(\beta=-0.06, t=-5.93, \beta=0.33, t=4.13$, significant at or below the 0.05 level). This finding shows that the tenure of auditor has a negative effect on the value relevance and a negative signal send to market capital and firms audited by government audit have the value relevance higher than private audit and result to market reaction.

Regarding our $\mathrm{H}_{7}$ hypothesis, table 4 appears that that audit reports is not significant $(\beta=0.01, t=0.18$, significant at or below the 0.05 level). However, firms with the tenure of auditor and type of auditor is negatively and positively significant in turn $(\beta=-0.06, t=-5.85$, $\beta=0.35, t=4.51$, significant at or below the 0.05 level). This finding shows that unqualified audit report and other audit reports are not value relevance in capital market and not lead to market reaction but the tenure of auditors has a negative effect on the value relevance and a negative signal send to market capital and firms audited by government audit have the value relevance higher than private audit. 
Table 4. Summary statistics from equations

\begin{tabular}{|c|c|c|c|c|c|c|c|}
\hline Variables & Model 1 & Model2 & Model 3 & Model 4 & Model 5 & Model 6 & Model 7 \\
\hline$\alpha$ & $\begin{array}{c}0.79 \\
(20.22)^{*}\end{array}$ & $\begin{array}{c}0.66 \\
(14.72)^{*}\end{array}$ & $\begin{array}{c}0.95 \\
(20.91)^{*}\end{array}$ & $\begin{array}{c}0.66 \\
(12.49)^{*}\end{array}$ & $\begin{array}{c}0.96 \\
(19.51)^{*}\end{array}$ & $\begin{array}{c}0.86 \\
(14.42)^{*}\end{array}$ & $\begin{array}{c}0.83 \\
(14.29)^{*}\end{array}$ \\
\hline BV & $\begin{array}{c}0.35 \\
(6.83)^{*}\end{array}$ & $\begin{array}{c}0.39 \\
(7.34)^{*}\end{array}$ & $\begin{array}{c}0.44 \\
(8.19)^{*}\end{array}$ & $\begin{array}{c}0.38 \\
(7.32)^{*}\end{array}$ & $\begin{array}{c}0.44 \\
(8.19)^{*}\end{array}$ & $\begin{array}{c}0.47 \\
(8.85)^{*}\end{array}$ & $\begin{array}{c}0.47 \\
(8.78)^{*}\end{array}$ \\
\hline EPS & $\begin{array}{c}0.56 \\
(5.52)^{*}\end{array}$ & $\begin{array}{c}0.55 \\
(5.37)^{*}\end{array}$ & $\begin{array}{c}0.49 \\
(4.79)^{*}\end{array}$ & $\begin{array}{c}0.54 \\
(5.35)^{*}\end{array}$ & $\begin{array}{c}0.49 \\
(4.81)^{*}\end{array}$ & $\begin{array}{c}0.46 \\
(4.58)^{*}\end{array}$ & $\begin{array}{c}0.46 \\
(4.58)^{*}\end{array}$ \\
\hline Audit Reports & $\begin{array}{l}-0.035 \\
(-0.60) \\
\end{array}$ & & & $\begin{array}{l}-0.0001 \\
(-0.00)\end{array}$ & $\begin{array}{c}-0.03 \\
(-0.48)\end{array}$ & & $\begin{array}{c}0.01 \\
(0.18)\end{array}$ \\
\hline Auditor Type & & $\begin{array}{c}0.33 \\
(4.20)^{*} \\
\end{array}$ & & $\begin{array}{c}0.32 \\
(4.12)^{*}\end{array}$ & & $\begin{array}{c}0.33 \\
(4.13)^{*}\end{array}$ & $\begin{array}{c}0.35 \\
(4.51)^{*} \\
\end{array}$ \\
\hline Tenure of Auditor & & & $\begin{array}{c}-0.06 \\
(-5.58)^{*}\end{array}$ & & $\begin{array}{c}-0.06 \\
(-5.57)^{*}\end{array}$ & $\begin{array}{c}-0.06 \\
-(5.93)^{*}\end{array}$ & $\begin{array}{c}-0.06 \\
(-5.85)^{*}\end{array}$ \\
\hline R-sq & 0.06 & 0.05 & 0.08 & 0.05 & 0.08 & 0.07 & 0.07 \\
\hline F- test & $50.80^{*}$ & $57.24 *$ & $62.43 *$ & $42.70^{*}$ & $46.75^{*}$ & $42.37 *$ & $41.90 *$ \\
\hline
\end{tabular}

\section{Conclusion and remarks}

The use of accounting information in stock market users' fundamental valuation models is well documented in the accounting literature and also, the value relevance of accounting information has been the interest issues for capital market researches in recent years. Accounting information is relevant if it is capable of making a difference in decision made by investors; even if already know from other sources (SFAC No.8, FASB, 2010, paragraph QC6). The demand for an audit function is based on the belief that auditors facilitate market transactions by providing an opinion on financial statements, which should help to reduce the information asymmetry between the company and its potential investors (Dye, 1993; Titman and Trueman, 1986). In addition, central to this demand is the belief that auditors' opinions convey the useful information to external users of financial statements (Chow, 1983). Thus, it expected that audit have the value relevance in capital market. This study investigates the value of relevance of audit report, the type of auditor and the tenure of auditor in the Iranian context. We use a long test window for the test of hypothesis.

The results of descriptive statistics are following. The percent trend of type of auditor indicates that audit privatization increase in the Iranian capital market during the last decade. Also, the percent trend of unqualified audit opinion is increase in the Iranian capital market during the last decade. Earnings per share and book value per share is significant in the all equations and hence, those have the value relevance in the capital market. This result is consistent with Lee and lee (2011) and Pourheydari and Ali Ahmadi (2008). The results indicate that audit report have not the value relevance in capital market. Thus, between unqualified audit report and other audit reports is not different in capital market. The results indicate that the type of auditor has the value relevance in capital market. Thus, between 
Audit Organization and private audit is different in capital market. This finding is consistent with prediction on lin and et al (2009), Holthausen and Verrecchia (1988), Kothari (2001), Krishnan (2003), Watkins et al. (2004). The results indicate that the tenure of auditor is the value relevance in capital market. Thus, between the long time and the short time of the tenure of auditor is different. This result is consistent to Ghosh and Moon (2005).

On the basis of results we recommend that market regulators which to decrease the negative effect of the tenure of auditor on the value relevance determine the time period for the tenure of auditors. Considering the research results, we find audit privatization and increase competition in audit can impact on the value relevance. So, we suggest to market regulators and Iranian Association of Certified Public Accountants (IACPA) to exactly monitor and control on the presented services of private audit firms to improve the value relevance of accounting information in the capital market. This study contributes to the empirical evidence on the value relevance of audit factors in emerging markets and also, to reveal the effect of audit privatization on the value relevance in emerging markets.

\section{References}

Barth, M. (2006). Research, standard setting, and global financial reporting. Foundations and Trends ${ }^{\circledR}$ in Accounting, 1(2), 71-165. http://dx.doi.org/10.1561/1400000002

Barth M.E., W. H. Beaver, \& W.R. Landsman. (2001). The relevance of the value relevance literature for financial accounting standard setting: another view. Journal of Accounting and Economics, 31(1), 77-104. http://dx.doi.org/10.1016/S0165-4101(01)00019-2

Balsam, S., J. Krishnan, \& J.S. Yang. (2003). Auditor Industry Specialization and Earnings Quality. Auditing: A Journal of Practice \& Theory, 22(2), 71-97.

Brown. S., K. Lo., \& T. lys. (1999). Use of $\mathrm{R}^{2}$ in accounting research: meaning changes in value relevance over the last four decades. Working paper.

Bich Ngoc.L.T (2010). Value relevance of accounting information for investors by large listed company in Vietnamese stock market. Unpublished PHD dissertation. HELP University College.

Change. H. Cheng. C.S and k.J. Reichelt. (2010). Market Reaction to Auditor Switching from Big 4 to Third-Tier Small Accounting Firms. Auditing: A Journal of Practice \& Theory, 2, 83-114.

Chow, C.W. (1983). On the Measurement of Auditing Standards, Journal of Business Finance \& Accounting, 10, 21-35. http://dx.doi.org/10.1111/j.1468-5957.1983.tb00410.x

Dye, R. (1993). Auditing Standards, Legal Liability, and Auditor Wealth. The Journal of Political Economy. http://dx.doi.org/10.1086/261908

DeAngelo. L. (1981). Auditor Size and Audit Quality. Journal of Accounting and Economic, 3(3), 183-199. http://dx.doi.org/10.1016/0165-4101(81)90002-1 
DeFond, M.L. (1992). The Association Between Changes in Client Firm Agency Costs and Auditor Switch. Auditing: A Journal of Practice \& Theory, 11, 26-31.

Farajzade.H, \& N. Makarem (2011). The Effect of Size and Type of Auditor on Audit Quality. International Research Journal of Finance and Economics, 80, 121-137.

Francis, J., \& K. Schipper. (1999). Have Financial Statements Lost Their Relevance? Journal of Accounting Research, 37(2), 319-352. http://dx.doi.org/10.2307/2491412

Ghosh. A., \& D. Moon. (2005). Auditor Tenure and Perceptions of Audit Quality. The Accounting Review, 80(2), 585-612. http://dx.doi.org/10.2308/accr.2005.80.2.585

Gujarati,D. (2004). Basic Econometrics. McGraw-Hill. Fourth Edition.

Holthausen. R., \& R. Verrecchia. (1988). The Effect of Sequential Information Releases on the Variance of Price Changes in an Inter-temporal Multi-asset Market. Journal of Accounting Research, 26(1), 82-106. http://dx.doi.org/10.2307/2491114

Holthausen, R.W., \& R.L. Watts. (2001). The relevance of the value- relevance literature for financial accounting standard setting. Journal of Accounting and Economics, 31(1), 3-75. http://dx.doi.org/10.1016/S0165-4101(01)00029-5

Ittonen, K. (2012). Market reactions to qualified audit reports: research approaches. Accounting Research Journal, 25(1), 8-24. http://dx.doi.org/10.1108/10309611211244483

Ittonen, K. (2009). Audit report and stock market. Unpublished PHD dissertation. UNIVERSITAS WASAENSIS.

Kang-tao.YE and Ying li.C. (2011). Audit quality and value relevance of faire value accounting. Journal of Shanghai Lixin University of Commerce, 3.

Kothari. S.P. (2001). Capital Markets Research in Accounting. Journal of Accounting and Economics, 31, 105-231. http://dx.doi.org/10.1016/S0165-4101(01)00030-1

Krishnan. G.V. (2003). Auditor Quality and the Pricing of Discretionary Accruals. Auditing: A Journal of Practice \& Theory, 22(1), 109-126.

Lee,H.L, \& H. lee. (2011). The Value Relevance of Summarized Accounting Information and Audit Quality. Working paper. in Second International Conference of the Japanese Accounting Review Presented. http://dx.doi.org/10.1596/1813-9450-5732

Lee, H., \& T. Wang, (2003), Value Relevance: Book Value of Equity and Intrinsic Value, Review of Securities and Futures Markets, 15(3), 63-103.

Lin. Z.J., Liu. M., \& Z. Wang. (2009). Market Implications of the Audit Quality and Auditor Switches: Evidence from China. Journal of International Financial Management and Accounting, 20(1), 35-78. http://dx.doi.org/10.1111/j.1467-646X.2009.01026.x

Martinez. M.C.P., A.V. Martinez, \& M.A.G. Benau. (2003). Reaction of the Spanish Capital Market to Qualified Audit Reports. European Accounting Review, 13(4), 689-711. http://dx.doi.org/10.1080/0963818042000216848 


\section{Macrothink}

Nobes, C.W. (1983). A judgmental international classification of financial reporting practices. Journal of Business Finance and Accounting, 10(1), 1-19. http://dx.doi.org/10.1111/j.1468-5957.1983.tb00409.x

Ohlson, J. A. (1995). Earnings, Equity Book Values, and Dividends in Equity Valuation. Contemporary Accounting Research, 66-687. http://dx.doi.org/10.1111/j.1911-3846.1995.tb00461.x

Pourheydari, O., \& S. Ali Ahmadi. (2008). Accruals and Cash Flows in Equity Valuation: Iranian Case. Middle Eastern Finance and Economics, 2, 5-15.

Titman, S., \& Trueman, B. (1986). Information Quality and the Valuation of New Issues, $\begin{array}{llll}\text { Journal of Accounting and Economics, } & \text { 159-72. }\end{array}$ http://dx.doi.org/10.1016/0165-4101(86)90016-9

Watkins, A.L., W. Hillison, \& S.E. Morecroft. (2004). Audit Quality: A Synthesis of Theory and Empirical Evidence. Journal of Accounting Literature, 23, 153-193. 